\title{
Acknowledging Strength in Plurality: The World Social Forum 2016 Through the Prism of Assemblage Thinking
}

\author{
CARMINDA MAC LORIN \\ University of Montreal, Canada \\ NIKOLAS SCHALL \\ University of Trier, Germany
}

\begin{abstract}
In this article, we contribute to debates regarding the nature and role of the World Social Forum (WSF) in the post-2010 period by employing the prism of assemblage thinking. By using the WSF 2016 held in Montreal, Canada as a case study, we outline the political potential of the assemblage approach, which allows activists and researchers of social justice and contemporary contentious spaces to address some of the intrinsic paradoxes in such mobilizations. The observation of some paradigmatic moments from the WSF 2016 offers a glimpse into the heterogeneity that shapes it. We address elements as diverse as actors' intentionalities, migration policies, urban landscapes, power relations, contents, and absences, arguing that assemblage thinking opens up innovative possibilities for analyzing multidimensional phenomena such as the WSF.
\end{abstract}

KEYWORDS World Social Forum; assemblage; social movements; Canada; diversity

\section{Introduction}

Montreal, Tuesday August 9th, 2016, 3pm

It is the $9^{\text {th }}$ of August 2016. I arrive by bicycle at the intersection of Roy Street and Park-La Fontaine Avenue. I see a vast crowd composed of multiple, diverse groups of people. Maybe a couple of thousand? I see the waving flags of big unions, and numerous people huddled together wearing orange and blue, obviously belonging to the same organization. While I wander along, I see them rehearse some kind of performance, while others make cardboard signs. Coming closer to Sherbrooke Street, I spot the white registration tent and continue to make my way toward the march, accompanied by the familiar tunes of Bob 
Marley playing on a nearby stereo. On the way, I spot a group of people wearing feathers: some bare chested, others wearing sneakers, jeans and sweaters. Near them I see "Hiawatha Belts" and a Mohawk Warrior flag. I try to overtake the march to observe its entirety. I see pro-Chavez posters as well as a sign reading "I am a victim of Chavez;" I see the handmade cardboard signs in the shape of silhouettes representing the people from other countries whose visa applications were denied; I see a huge Palestinian flag carried by dozens of people; I see Steelworkers, rainbow flag bearers, and many more. (Vignette from participant observation by N. Schall)

This short ethnographic vignette introduces the opening march of the 12th edition of the World Social Forum (WSF), which took place from August $9^{\text {th }}$ to $14^{\text {th }}, 2016$ in downtown Montreal and hosted roughly 35,000 people. The

WSF has often been referred to as the largest gathering of global civil society. Every one to two years, up to 150,000 people have met for five or six days in different locations around the world to take part in the WSF, as participants or organizers of its countless activities (e.g., conferences, round tables, workshops, artistic happenings, and assemblies). In the last 15 years, the literature on the WSF and social forums more generally has grown significantly (Conway, 2013, pp. 16-21). It has introduced various analytical tools and perspectives to capture the complexity of this phenomenon, as well as distinct ideas and aspirations concerning its future developments.

The purpose of this article is twofold. First, we contribute to these reflections by interrogating the analytical potential of the assemblage concept to enhance our understanding of the World Social Forum as a socio-political phenomenon in the post-2010 period. Second, we scrutinize the ability of assemblage thinking to address practical challenges in the WSF process, namely the seemingly dichotomous positions on its nature and purpose (i.e., as a space or as an actor), thereby addressing the concept's usefulness for social justice struggles. We achieve these ambitions by first outlining how the WSF emerged within the alter-globalization movement. We then provide an operational overview of assemblage thinking and deploy it as a heuristical framework to analyze our ethnographic material. We thereby illustrate the heterogeneity of the WSF and elucidate different components of the 2016 WSF's multiplicity: actors and their intentionalities, places, and policies. At specific points, we combine the assemblage approach with perspectives from actor-network theory (Müller \& Schurr, 2015, p. 7) and performativity studies (Butler, 2015) to address inherent tensions and contradictions, as well as processes of negotiation, in our analysis. We show that the heterogeneity of the WSF animates contestation between those who think the WSF should be a "space" and those who want it to become an "actor." We conclude by discussing the potential we think assemblage thinking holds for organizers and activists on a broader scale, in additional to its analytical usefulness.

The article is a collaboration between two activist-researchers with varying experiences and backgrounds. We share an academic education in anthropology, which informs our understanding of the assemblage concept, 
but we had different introductions to the WSF 2016 and have since forged distinct relationships with it. Carminda Mac Lorin was involved in the coordination of the WSF 2016, as well as in the nomination process for holding the event in Montreal. Nikolas Schall encountered the WSF while pursuing participatory action research on practices of cosmopolitan solidarity. The paper draws on our activist engagement as well as more traditional qualitative research practices, including interviews conducted during the WSF 2016 and thereafter. Alhough we grew up in different places and contexts and are positioned dissimilarly regarding common categories of difference (i.e., gender, nationality, first language, and ethnic background), we both follow educational routes in Western educational institutions. We articulate this positioning in order to critically situate our perspective; we believe this is especially important in relation to discussions about the WSF, which has been understood as an attempt to create an epistemology of the South capable of challenging occidental modernity and its science (see de Sousa Santos, 2004, p.13).

The World Social Forum: From its Context of Emergence to the WSF 2016 in Montreal

\section{Alter-Globalization and Post-2010 Movements}

The alter-globalization movement or global social justice movement emerged in the late 1990s, bringing together very diverse social actors (e.g., Indigenous activists, ecologists, feminists, non-governmental organizations, trade unionists, anti-militarists, and political parties of the left) in formal and informal national and transnational networks. Far from establishing a single model or a precise set of objectives, alter-globalization instead proposes plurality as its most important quality. Over the last two decades the alterglobalization movement has mobilized hundreds of thousands of people through counter-summits such as those protesting the World Trade Organization in Seattle in 1999, the Summit of the Americas in Quebec in 2001, and through various social forums. Recently, several protest movements have been discussed against the backdrop of alter-globalization, including the so-called Arab Spring, Indignados, and Occupy. These are designated as post-2010 protests or "movements of the crisis" (Della Porta \& Mattoni, 2014). Their continuities and discontinuities with previous waves of activism have been outlined by other scholars (Della Porta \& Mattoni, 2014). As we will demonstrate, both the alter-globalization movement and a constellation of post-2010 movements served as models for organizing within the WSF 2016, and continue to influence how the Forum deals with questions of process, procedure, and inter-group communication. 
The World Social Forum

The first WSF was held in Porto Alegre, Brazil in 2001. It was intended by its organizers to be a counterweight to the Davos Economic Forum. The slogan of the WSF ("another world is possible") and its main guidelines were stated in its Charter of Principles (WSF, 2001), a normative document that was adopted after the first WSF to define the Forum's key principles. The Charter outlines the Forum's identity as a space where opposition "to neo-liberalism and to domination of the world by capital" is expressed with the following characteristics: openness to plurality in civil society (thus excluding political parties and armed organizations), non-hierarchical relations, democracy and anti-discrimination, and encouragement of networking and collaboration (WSF, 2001).

As Chico Whitaker (2004, p. 116), one of the first proponents of the WSF points out the Forum became a platform for the plurality of alterglobalization; it proposes an initiative that translates into a concrete space of encounter for those around the planet who seek to counter imperialisms, proposing alternatives to current economic and social systems. Although the WSF's field of action is described in its Charter, its scope and the way participants deal with its intrinsic diversity are still matters of debate and negotiation.

\section{The WSF 2016 in Montreal}

In 2016 the WSF for the first time took place outside of the Global South, in Montreal, Quebec. The WSF 2016 Collective that proposed Montreal to the International Council of the WSF based its argument on the need to address the apparent division between the Global North and South. The WSF Collective stated that solidarities need to transcend boundaries in order to address the pitfalls of aggressive and hegemonic global neo-liberalism.

The 2016 Collective was initially constituted by people who had been involved in the Quebec Social Forums (2007, 2009), the Occupy mobilizations (2011), the Quebec Spring (2012), ${ }^{1}$ and other civil society groups or organizations. The Collective distinguished its posture from that of previous WSF organizers by trying to bring together the perspectives of citizens and organizations through a prefigurative organizational process (Gordon, 2018, p. 3; Leach, 2013, p. 1), instead of relying mainly on large institutions (e.g., the biggest local unions or non-governmental organizations). Their understanding of the political scope of the WSF recalled

\footnotetext{
${ }^{1}$ The Quebec Spring is also referred to in French as the Maple Spring ("Printemps érable"), a name inspired by the Arab Spring and the importance of maple trees to Quebec's economy and culture. In 2012, students in Quebec started massive mobilizations against the rise of tuition fees that the provincial government was planning for the years to come. It was the longest student strike in Canadian history, lasting almost seven months.
} 
that of the post-2010 mobilizations, as articulated by Marina Sitrin (2012, p. 62) referring to Occupy Wall Street: "part of this politics, as described by people all over the world, is the need to come together, do so without hierarchy, and do so in open spaces, where not only all can look at one another, but where a space in society is opened up and changed ."

\section{Reading the WSF Through Assemblage Theory}

The concept of assemblage offers the possibility of considering complex phenomena that emerge through the interaction of multiple autonomous components that can include human perspectives, discourses, and agency, but also material and other contextual and non-human elements. It originates in the work of Deleuze and Guattari (1988) and was especially developed in $A$ Thousand Plateaus. Since then it has been employed, developed and shaped in a range of disciplines, in different ways and to different ends (Conway, Thorburn, \& Osterweil, 2016, p. 5; Müller \& Schurr, 2015 pp. 218-219). DeLanda's systematization of assemblage thinking has become an important analytical tool to structure contemporary research fields, and is often used to frame messy, inconsistent, complex and entangled phenomena (Collier, 2006; Hess, Moser, \& Schwertl, 2013; Marcus \& Saka, 2006; Ong \& Collier, 2005; Rabinow, 2011). The concept's application hints at one of its core potentials: to conceptualize the relationship of heterogeneous parts and wholes, or (selfsubsisting) fragments and multiplicities (Nail, 2017, p. 23).

We deploy the concept of assemblage to enrich conceptualizations of the WSF with regard to its inherent tension between diversity and unity. Our understanding of assemblage thinking is based notably on DeLanda's A New Philosophy of Society: Assemblage Theory and Social Complexity (2006), as well as Assemblage Theory (DeLanda, 2016) and its subsequent critique by Thomas Nail (2017).

The Multiplicity of the WSF Assemblage: Heterogeneous Parts in a Fragmentary Whole

One of Deleuze's basic descriptions defines an assemblage as "a multiplicity which is made up of many heterogeneous terms and which establishes liaisons, relations between them" (Deleuze \& Parnet, 2007, p. 69). The relationships between the elements that compose an assemblage are understood as "relations of exteriority," meaning connections of selfsubsistent elements that can be related to one another, detach and exist by themselves, or even be re-combined (DeLanda, 2006, p. 19). "Multiplicity" here refers to an alternative logic to that of organic unities. The wholes are only fragmentary and never complete, as they are always emerging, changing 
with added and subtracted elements, as well as through the constantly shifting relations between them.

The concept of assemblage can be effectively applied to the WSF as a phenomenon assembling highly heterogeneous components in a fragmentary whole. A myriad of diverse elements constitute the WSF: 13 world events since 2001 (and countless regional, local and thematic events); local contexts shaping important elements of each WSF; constantly evolving methodologies in the application of the principles of the Charter; and hundreds of thousands of people around the world observing, living and interpreting a WSF. Each WSF in its specificity (and the continuous process constituted by all its editions) emerges as the aggregation of all these different elements, which are already assemblages themselves, and even assemblages of assemblages (DeLanda, 2006, p. 6). The WSF as a "fragmentary whole" is assembled around the principles announced in the Charter and is embodied in each iteration at a specific time and place, thereby reinforcing a symbolic sense of unity and strength of a so-called global civil society.

To illustrate the usefulness of the assemblage concept to encompass the intrinsic diversity of the WSF phenomena, we will explore key moments of the WSF 2016. Drawing on the methodological reflections of Maria Schwertl (2013), we focus our attention on ethnographic experiences including the one offered at the beginning of this article.

The WSF as an Assemblage of Assemblages: The Indigenous Opening Ceremony

Montreal, Tuesday August 9th, 2016, 6pm

At around six in the evening, we arrive at "Place des Arts," a square surrounded by skyscrapers at the heart of Montreal's city centre. Tens of thousands of people assemble in front of the main stage. Five people walk up on stage. One is bare chested, wearing a headdress consisting of antlers and feathers, another a leather jacket, the third a blouse, a vest and a medicine wheel displaying the slogan "Idle No More." Another holds a cardboard sign showing the hashtag $M M I W G$, and the final person proudly displays a Hiawatha Beltflag. The elder begins a speech in Kanien'kehá:ka language. He is followed by the bare chested man, who welcomes everyone in English "all of you from all around the world, here on Turtle Island, and especially on Kanien'kehá:ka territory." His speech is translated into French and Spanish. One of the speakers from Idle No More takes the microphone and speaks to the audience about First Nations struggles. She addresses the problem of visa restrictions for the WSF, and compares those barriers to state policies that exclude and discriminate against First Nation peoples. She ends by saying that "Canada is a country that is changing and that needs to change under the pressure of its citizens." After the opening ceremony, my friends and I take a much-needed dinner break, which we spend in a nearby vegan restaurant chain. It is filled with the participants wearing orange and blue, whom I saw earlier on. We then 
head back to "Place des Arts." As we arrive, I turn around and take in the skyscrapers that wear the emblems of financial institutions and global hotel chains, set against the dark sky. (Ethnographic vignette from participant observation by N. Schall) ${ }^{2}$

The ethnographic vignettes from the opening day of the WSF 2016 hint at a central feature of the venue: the unceded status of Montreal, which means that there has never been any agreement or treaty that has transferred land title from Indigenous Nations to Settler ownership or control. The WSF opening started with an Indigenous opening ceremony by representatives from the Kanien'kehá:ka Nation (Mohawk), which - despite the fact that the territory of today's Montréal has been inhabited and used by many different Indigenous peoples, communities and Nations - is widely recognized as the custodian of the territory. ${ }^{3}$ This opening must be understood against the backdrop of the historical positionality of Indigenous people in the WSF process (Conway, 2011, pp. 224-225; 2013, pp. 151-157) and vis-à-vis the Montreal organizing process, which took place in the context of the aforementioned Idle No More Movement (Kino-nda-niimi Collective, 2014), the People's Forum in 2014 that highlighted the importance of First Nation Voices (O'Keefe, 2014), and a more general change in the Quebec societal climate regarding First Nations people, sometimes referred to as "era of reconciliation" (see Taiaiake Alfred, 2016, for a critical analysis of this "era of reconciliation"). The ethnographic vignettes also enables an appreciation of how local struggles in different places can relate and collectively put forward a stronger message. They come together in an assemblage "composed of pre-existing things that, when brought into relations with other pre-existing things, open up different capacities not inherent in the original things but only come into existence in the relations established in the assemblage" (Rabinow, 2011, p. 14).

The first person who got on stage after the ceremonial opening was Bertita Cáceres, daughter of Berta Cáceres, an internationally known environmental and Indigenous rights activist from Honduras who was murdered in 2016. Bertita was holding a cardboard sign calling for "Justice for Berta" (see Figure 1). She joined Melissa Mollen-Dupuis from Idle No More and Maïtée Labrecque Saganash, an activist from the Indigenous Cree Nation, who were already on stage. The latter was holding a cardboard sign in support of a Twitter campaign that had been drawing attention to the issue of Missing and Murdered Indigenous Women and Girls in Canada. Thus, gathered on stage

${ }^{2}$ Idle No More is a grassroots Indigenous movement that emerged in December 2012 as a response to legislative changes that removed protection from waterways. It developed into a more general movement struggling for Indigenous sovereignty and Indigenous rights. First Nation is used as a term for the diverse Indigenous Nations in Canada. First Nations, Metis and Inuit people form Canada's Indigenous population.

${ }^{3}$ See e.g., the territorial acknowledgement of Concordia University:

https:/www.concordia.ca/about/indigenous/territorial-acknowledgement.html 
were representatives of struggles from different places that connected in their specificities and commonalities.

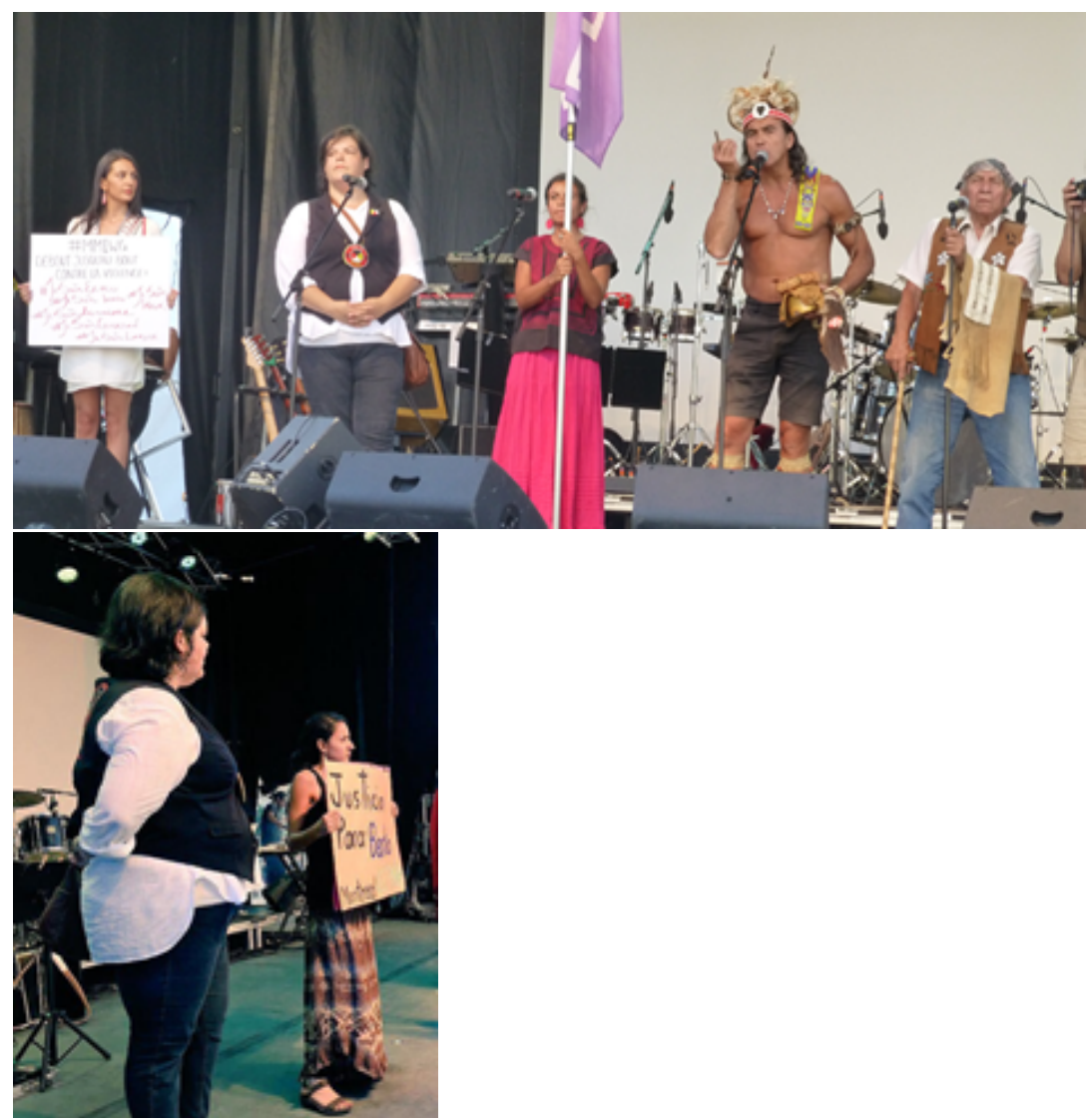

Figure 1. The Opening Ceremony (Photo: World Social Forum 2016 [@fsm2016wsf; August 10, 2016])

Paradigmatically, the images in Figure 1 illustrate transnational solidarities and connections in the Indigenous rights movements, which themselves form a specific assemblage that was highly visible on this opening day. They demonstrate the aspiration of globality within the WSF without neglecting plurality at local levels, while acknowledging and making explicit their mutual interconnectedness. This global-local nexus can be recognized as the conjunction of unity and plurality that characterizes the WSF. This perspective is also highlighted in Ong and Collier's (2005) use of assemblage thinking, where they break down the supposed opposition between the local 
and global, a common issue in debates about globalization (Collier, 2006, p. 400).

Another telling scene unfolded during interviews with the First Nations representatives of the opening ceremony, who represented divergent positions even within a seemingly similar struggle. The bare-chested man, Stuart Junior, is a member of the the Mohawk Traditional Council, which has been a prominent critic of the organizing and protest practices of the Idle No More movement that Melissa Mollen-Dupuis, standing close to him on stage, represented (see Mohawk Traditional Council, 2013). The different perspectives presented here point to different assemblages that together create what we can interpret as "an Indigenous opening assemblage," being in itself a distinctive element of the WSF 2016 assemblage.

This example illustrates that the juxtaposition of the different elements of assemblage does not erode their specificity. Instead, they maintain relations of exteriority, which DeLanda (2006) underlines as being fundamental when addressing linkages between different parts of an assemblage (in this case, diverse Indigenous perspectives and local struggles). Each element is selfsubsistent (its identity not defined by the link to others) and can be detached and joined with other assemblages (DeLanda, 2006, p. 19).

Heterogeneous Intentionalities: The Organizers' Perspectives on Unifying Plurality

Another significant element of this WSF that can be looked at through the prism of assemblage thinking is intentionalities. Having interviewed different people involved in the WSF 2016 Collective and collaborated with many of them, it was clear that people get involved for diverse reasons. The WSF had a strong symbolic appeal by itself as a meeting space, offering the possibility of connecting many different perspectives.

Carminda Mac Lorin's experience participating for three years in the organizing process and eventually becoming a coordinator of the WSF 2016 Collective revealed on a day-to-day basis the constant need to deal with the tensions between diversity and unity. In different contexts, it became crucial to present the WSF as a unified and coordinated whole (e.g., for those who joined the organizational process, to plan logistics, to build mobilization tools, for the partners, for the media). The Charter of Principles of the WSF (which acknowledging the Forum's essence as a space open to diversity), complemented by the Charter of the WSF 2016 Collective (which emphasizes the organizational process as being open, horizontal, transparent, independent, and self-organized), guided this quest for coherence. However, the intention to build a a sense of unity contrasted with explicit willingness to encourage a horizontal plurality (e.g., amongst organizers and participants, between cultural perspectives, genres, generations, struggles), seen as one of the main intended purposes of the WSF. 
Returning to our example of the opening ceremony, an interview with one of its main organizers indicated that because plurality was conceived as the strength of the WSF, it was therefore intentionally staged. The opening day was imagined as the assembling of different people, positions and struggles, who together made up the WSF 2016. This coming together was in flux never stabilized and disassembled directly afterwards - but one could speak of a moment of symbolic unity of the many positions. The public representation of this heterogeneity - as a performance of human diversity was considered by the organizers as itself a politically coherent action.

\section{Place as a Constitutive Element of the WSF Assemblage}

DeLanda (2016) states that the components of an assemblage can be read on a continuum, from expressive to material. The ethnographic vignette used previously illustrates this material/expressive continuum paradigmatically: the opening ceremony of the WSF was held in the material space of Montreal's sky scraper-dominated city centre, at the "Place des Arts," which is also a regular site for large commercial music shows, festivals, cultural events, and other kinds of consumption.

Reflecting on the words of Javier Auyero, we argue that DeLanda's perspective on the socio-material world has a consonance with the significance of place regarding protests:

Places are thus at once the terrain and the stakes of the politics of protest. Collective actions take place in physical places, which already have a special meaning. In turn, collective actions contribute to the transformation of meaning attributed to certain places. (Auyero, 2005, p. 130; authors' translation)

The expressive dimension of place can be identified in the organizers' intention to transform its meaning, in this case by putting in question the norm of settlement at the heart of colonial cities such as Montreal. One such acknowledgement of colonization and the unceded status of territory occurred during the opening ceremony. The act of renaming the areas where the WSF took place the "World Social Territory" can be understood as a second attempt to shift the symbolic and representational character of the places.

Although this transformation of meaning was attempted by groups who attended the WSF and appeared in some media reports, ${ }^{4}$ it never achieved a scope comparable to those longer-term protests that consistently transformed the meaning of places such as Taksim Meydan1, Puerta del Sol, and Platia Syndagmato. While these locations now seldom appear in international media without mention of the post-2010 mobilizations, Place des Arts has not come

\footnotetext{
${ }^{4}$ See e.g., reports by the World Fair Trade Association (http://wfto.com/news/world-socialforum-2016) and Cision (http://www.newswire.ca/fr/news-releases/forum-social-mondial-2016--journee-du-12-aout-2016--derniere-chance-pour-les-grandes-conferences-589904301.html).
} 
to be widely associated with the WSF 2016. Nevertheless, following Judith Butler (2015), one could see the impacts of this event on another level if we consider that a concrete experience of momentary and incomplete transformation in and of a place like this durably affects imaginative potentials:

Gatherings are necessarily transient, and that transience is linked to their critical function. One could say, 'but oh, they do not last,' and sink into a sense of futility; but that sense of loss is countered by the anticipation of what may be coming: 'they could happen at any time!' Gatherings such as these serve as one of democracy's incipient or 'fugitive' moments. (Butler, 2015, p. 20)

Building on these explorations of the expressive dimension of the place, we now focus on the material, "non-human" elements that shape the place (see Müller \& Schurr, 2015, p. 7). The skyscrapers mentioned above hint at the embeddedness of the WSF 2016 in a neoliberal surrounding. The vignette suggests that many participants went to nearby restaurants. This shows how important the surrounding capitalist infrastructure was to literally sustaining the protesters, and thereby points to moments when a reproduction of exclusions is taking place. The material non-availability of food demonstrates economic exclusions and privileges intrinsic to the place. What happened to those who couldn't spend their time in downtown Montreal or afford to sustain their physical needs there? How would the opening ceremony have been different, had it taken place in a less privileged northern neighbourhood?

Assemblage thinking, with its equal consideration of expressive and material dimensions, illuminates diverse aspects of the significance of place for the WSF. The attempted transformation from a neoliberal space into one of dissent was a transient phenomenon that nevertheless carried more durable imaginative potentials. It was also only a partial transformation, as the WSF did not become (and never aimed to be) independent from the surrounding economic and social structures. It remained necessarily embedded in certain social and economic structures and thereby reproduced certain exclusions.

\section{Policies and Absences as Elements of the WSF Assemblage}

Analyzing the WSF 2016 through the prism of assemblage thinking invites us to pay attention to other "more-than-human" constitutive elements. One of these is government policies. We are following an understanding of policies developed by Shore, Wright and Però (2011) who, referring to Bruno Latour, understand policies as "actants." They write, "policies have agency; they shift action; and, like machines, they perform tasks and are endowed with certain competencies" (Shore, Wright \& Però, 2011, p. 3). Canadian migration policies must in this way be understood as an integral element of the WSF 2016. Hundreds of participants were unable to attend the Forum because their 
visa applications were rejected. This absence was materialized in the form of cardboard silhouettes during the opening march, as seen in the ethnographic vignette and in Figure 2.

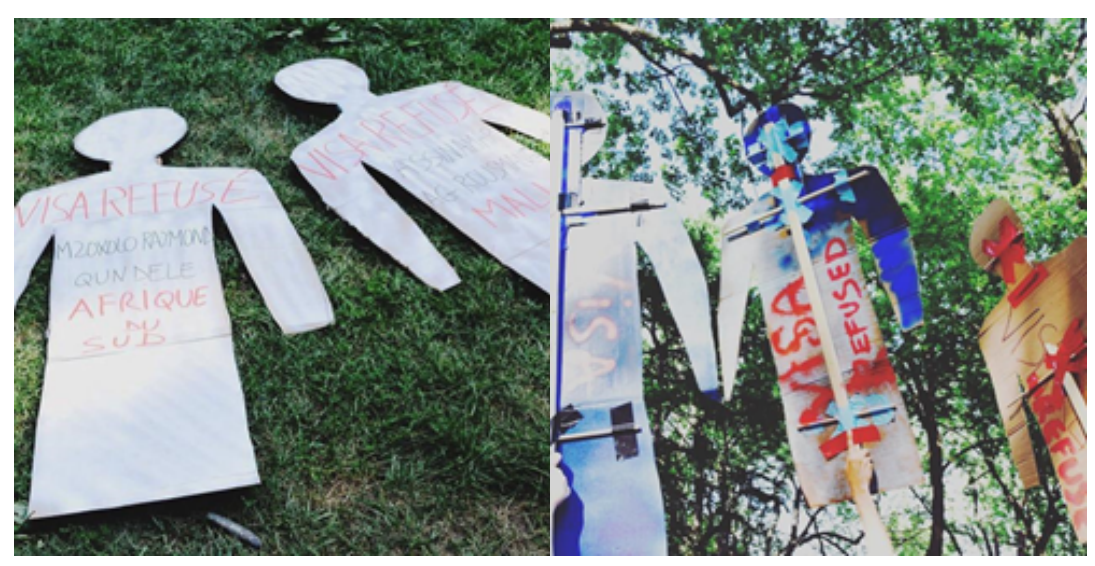

Figure 2. Silhouettes of absent persons (Photo: World Social Forum 2016 [@fsm2016wsf; August 10, 2016])

In the context of the WSF 2016 the visa issue was widely publicized by media reports, which highlighted restrictive visa policies of a country that is so often seen as a model for immigration policies. ${ }^{5}$

This making visible of what often stays unremarked illustrates what the Portuguese sociologist Boaventura de Sousa Santos (2004) argues to be one of the characteristics of social and political processes such as the WSF. "Absences" emerge through processes of exclusion and marginalization: "what does not exist is in fact actively produced as non-existent" (de Sousa Santos, 2004, p. 14). The sociology of absences appears to us a useful analytical tool, as it aims to confront the logics and dynamics of hegemonic rationalities that disqualify or make invisible certain entities or processes. Combined with an awareness of more-than-human elements, a sociology of absence allows us to see that exclusions become a property of the WSF 2016 assemblage. Understanding those exclusions as the product of interacting heterogeneous elements helps move beyond an understanding of exclusion as existing either on an individual or structural level. It allows us to recognize the paradox of a desired non-hierarchical, democratic and non-discriminatory space that simultaneously reproduces oppression (e.g., as we previously illustrated regarding space). Acknowledgement and awareness of this property of the assemblage enhances possibilities to deal with these contradictions.

\footnotetext{
${ }^{5}$ An overview of the media reporting on the 2016 World Social Forum is available at https://fsm2016.org/en/revue-de-presse
} 
Finding Coherence Through Processes of Negotiation

As we saw above through the examples of the opening ceremony assemblage, intentionalities of the organizers, place, policies and absences, assemblage thinking opens possibilities to grasp the constitutive heterogeneity of the WSF. However, deploying assemblage theory and following Rabinow (2011, p. 14), we could critically ask, what are the "different capacities not inherent in the original things" of this assemblage? Framed differently, what resulted concretely from assembling these heterogeneous elements and what were the consequences of tensions between the assembled elements? If plurality is evident within the WSF assemblage, where can we recognize the coherence of these elements? We are not able to provide a general overview of what resulted from this bringing together of heterogeneous elements, due to the huge scale of the event (tens of thousands of participants) and the characteristics of our qualitative approach. Nevertheless, the thousands of people from around the world who gathered during each WSF confirm its significant symbolic unifying appeal. This symbolic function of the WSF is reinforced by its pragmatic capacity to encourage interactions between its constitutive elements that would not exist otherwise.

To illustrate interactions motivated by the WSF, we use a third ethnographic vignette originating from the Agora of Initiatives that took place at the end of the 2016 Forum. It shows how elements that were central in the opening ceremony made connections and entered into negotiations.

Saturday, August 13, Jarry Park

On the second-to-last day of the $2016 \mathrm{WSF}$, an agora of initiatives, as it's called, takes place in Jarry Park. It is raining, so two huge white tents have been set up. There are several hundred people present in the two tents, discussing eleven different topics simultaneously. After a while, the members of the Mohawk Traditional Council who performed during the formal opening arrive. One of them interrupts a group discussion on the subject of "struggles and visions of indigenous peoples." He criticizes the attendees for the lack of First Nations representatives and starts to take the lead of the round circle discussion by setting certain discussion rules and procedures, such as "do not interrupt," "only the one who is holding the feather has the right to speak," etc... At a certain point, some people from the organizing collective want to finish with the discussion circles in order to continue with a next step in the planned agenda. They grab a microphone and call for attention. A sudden tension becomes noticeable. Activists beside me stand up, approach the organizers, and tell them not to interrupt Stuart Junior. People go back and forth between the stage with the microphone and the discussion circle with Stuart. Finally, the people from the circle move to the other tent and continue their discussion, while the program in the first tent continues. (Ethnographic vignette from participant observation by N. Schall)

As this example shows, the heterogeneous elements (i.e., various actors with diverging intentions and aims, and non-human elements such as the 
weather and the limitation of space in the tent) enter into processes of negotiation and conjunction. Although some of those processes were imagined and anticipated by the organizing collective and therefore factored into the program methodology of the WSF 2016, many others, such as the situation described in the vignette, were unexpected; these occurred spontaneously. The vignette illustrates a negotiation of what it means to concretely recognize Mohawk sovereignty in that specific moment and place. It raises the question of how to deal with Indigenous struggles as crucial - but still as specific ones among others - during a Forum held in Montreal. This negotiation process and others can be read as resulting from assembling such heterogeneous elements, and illustrates an inherent capacity of the WSF. The solution that was found (i.e., round circle discussions in one tent, continuation of the WSF methodology in the other) can be understood as the transient coherence between the elements, or the emerging multiplicity. Although at some moments it seems as if the heterogeneous elements were standing side by side and were only symbolically united by the fact that they came together during the WSF, often these elements joined in processes of negotiation and conjunction.

\section{Dealing with Intrinsic Diversity: How Assemblage Thinking Contributes to the "Space-Movement" Debate}

As we have shown above, assemblage thinking enables a nuanced understanding of a fragmentary whole built around the negotiation or conjunction of a diversity of perspectives, intentionalities, specific places, policies, exclusions, etc. It therefore raises a compelling potentiality for enhancing comprehensions of the WSF. This seems particularly true in light of the existing debate on how unity and plurality should be articulated to increase the Forum's political impacts. This discussion, considered by many as "the most discussed issue between organizers and Forum participants," (Whitaker, 2006, p. 37; authors' translation) is often referred to as the "spaceactor debate". In the following pages, we will describe the main ideas of this controversy, before explaining how assemblage thinking can offer a key to addressing it.

On the one hand, as mentioned before the Charter of Principles of the WSF (WSF, 2001) affirms its specificity as a plural, open meeting space that encourages horizontality and autonomy, fosters association of actors, and does not intend to represent the organizations that gather within it, nor to deliberate on their names. People who defend this conception of the WSF maintain that it should not aim to take one single position, as this would necessarily devalue the strength of its heterogeneity. In their opinion, this would not be compatible with its horizontal, plural and inclusive nature, which represents for them the intrinsic specificity of the WSF, as well as its potential as a new political process. 
On the other hand, since the beginnings of the WSF it has been questioned if such an open space can produce concrete political results that will contribute to change in the world, and how these results would look. Many participants as well as critics expressed fundamental doubts about the political impact of the WSF as a space, suggesting that it should become instead a political actor or movement. They argue that it is necessary to create a unified global entity representing the WSF as a whole, taking clear stands against crises and violations of human rights (Teivainen, 2004, p. 126) and defending democratic values (de Sousa Santos, 2004). According to de Sousa Santos (2004, pp. 99-100), an advocate of this view, the plurality of political positions, struggles, and demands should come to common standpoints and engage in joint actions, in order to make the WSF stronger.

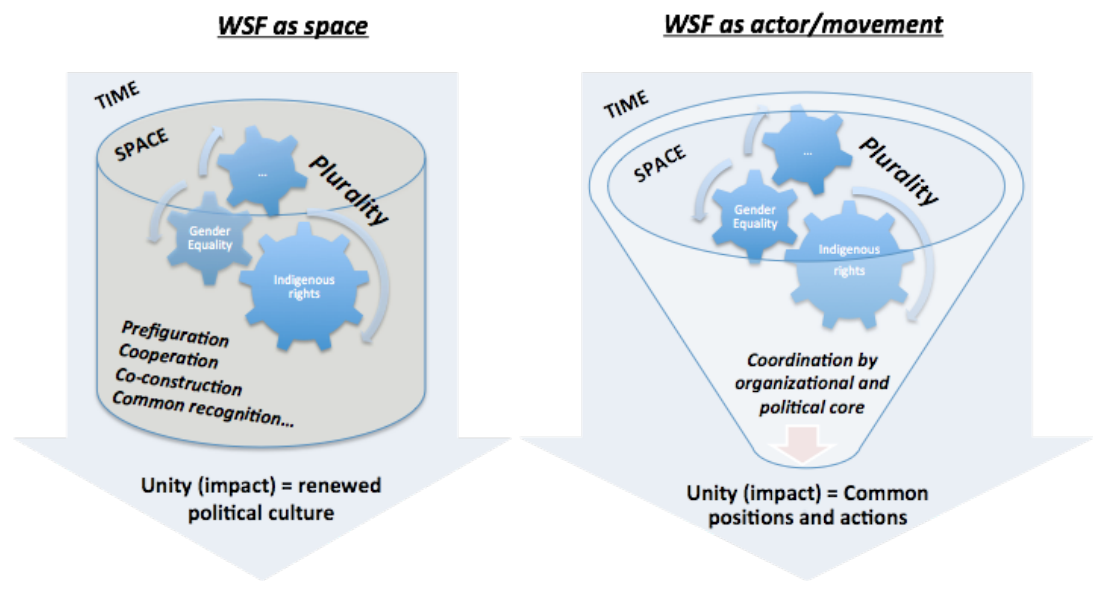

Figure 3. The two poles in the "space-actor debate"

We recognize in this debate two ontological and strategic perspectives regarding how unity and plurality should be articulated in order to increase the Forum's impact. Figure 3 represents these two perspectives graphically. On the left, we depict the approach that considers the WSF as a space. This perspective understands the construction of a renewed political culture (based on prefiguration, cooperation, co-construction and mutual recognition) and the horizontal coming together within plurality as fundamental outcomes of the WSF. On the right, we depict the perspective of the WSF as an actor, for whom plurality must be consolidated into common positions, with a view to carry out effective struggles against capitalist imperialism.

These dichotomous positions at times translate into vivid arguments, which we witnessed during the meeting of the International Council (IC) at the end of the WSF 2016 in Montreal. Indeed, the depth of the disagreement became apparent through the interventions of individuals (from within and outside of the IC) demanding that the IC should take clear positions on struggles in 
Brazil, Kurdistan and Palestine. This initiated a heated debate in which others defended the WSF as a space, and categorically rejected calls to issue such position statements.

At times, the possibility of a pernicious split along these lines seems likely: this would be a fatal blow to the WSF. In this context, various questions arise: Is it possible to speak in the name of the whole WSF without disarming the political potential of its plurality? Can the WSF as an open space mediate enough concerted actions, develop an impact and contribute to profound changes in the world? Is it possible to reconcile the perspectives of the WSF as actor, or space? These questions evidently do not have simple answers, but we think assemblage thinking can contribute to addressing them by offering an understanding of the WSF that allows for the coexistence of both perspectives: the Forum as space and actor.

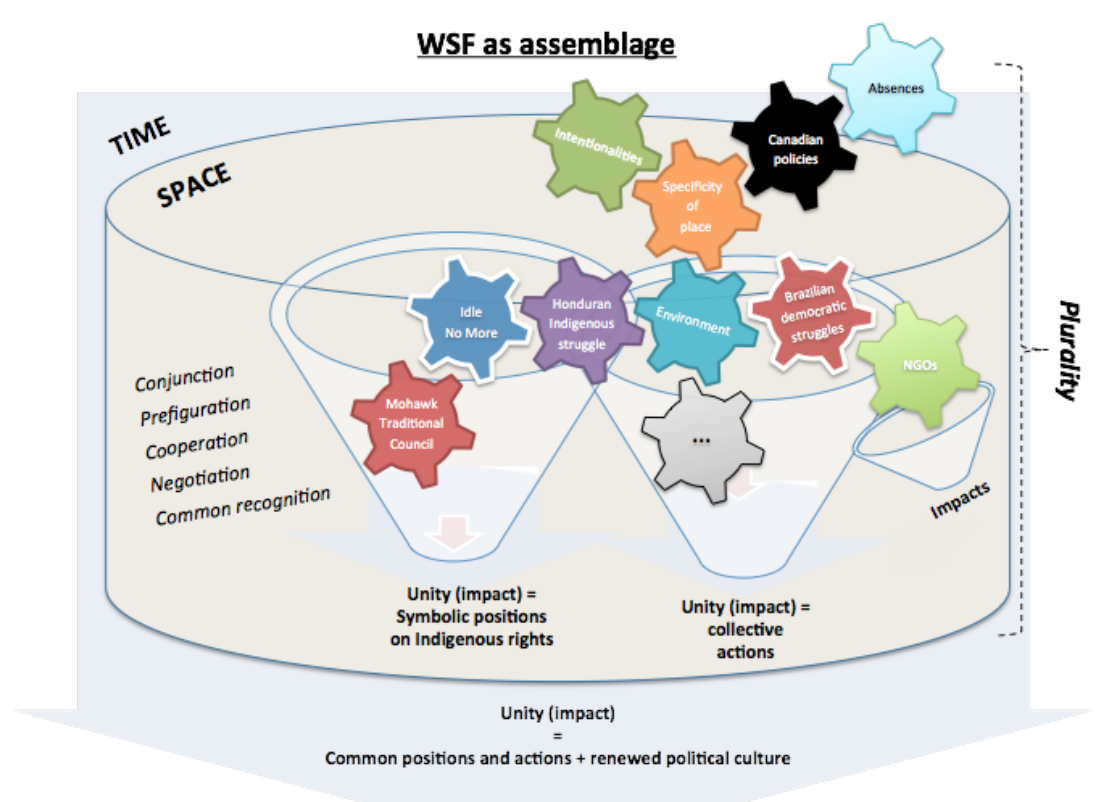

Figure 4. Assemblage model of World Social Forum

Figure 4 illustrates our perspective on how assemblage thinking, with its particular ontology of holding plurality in provisional and dynamic unity, can offer a path to move beyond the space-actor impasse. This is particularly pertinent in our view, as neither the space approach nor the actor approach alone seem sufficient to grasp the full potential of the Forum. On the one hand, the issues of denied visas, the WSF's embeddedness in a capitalist context, and restrictive migration regimes, show that the space approach does 
not keep its promise of horizontality: the WSF is not a power-free space. On the other hand, the example from the Agora of Initiatives mentioned above suggests that centralised procedures of decision-making - advocated for in the actor approach - are not the only way of developing shared positions. The heterogeneous, human and non-human elements coming together in this specific place and time enabled a situational shared understanding.

We propose that the quest for profound and diversified political impacts can include different approaches. Common positions and actions can be developed among its heterogeneous constituting elements, while also actively establishing a prefigurative interaction that eventually contributes to the consolidation of a renewed political culture. By acknowledging this, we agree with Glasius (2005, p. 248) who argues that, "in fact, it is to be hoped that it will not be resolved in one way or another," and thinks that it is the Forum's character as "both a locus of open deliberation and a meeting place for real world counter-hegemonic campaigns, that makes it such an interesting experiment, that has managed to attract so many" (Glasius, 2008, p. 249; see also Conway, 2013; Schröder, 2015; Teivainen, 2004).

\section{Acknowledging Strength in Plurality: The Political Potential of Assemblage Thinking Beyond Paradoxes}

In this article, we used the prism of assemblage thinking to introduce an actualization of the debates around the nature and role of the WSF in the post-2010 period. The observation of paradigmatic moments of the 2016 Forum provided a glimpse into the heterogeneity that shapes the WSF, which is composed of actors and their intentionalities, but also of elements such as migration policies, urban scapes, contents, and even absences. Our analysis of the interactions between these different elements also illustrates how a sense of coherence dynamically emerges from the WSF as a whole. Assemblage thinking opens an innovative possibility to analyze this multidimensional yet consistent phenomenon.

We suggested that in addition to its analytical value assemblage thinking can also provide an empowering perspective for activists and mobilizers who struggle for global justice, as it allows them to acknowledge and face certain contradictions and paradoxes that emerge in their contexts of plurality. This was first addressed by offering a reading of the 2016 WSF in which we explored how durable forms of power (e.g., North/South inequalities) interact and are articulated in specific situations while coexisting with the agency of the event's participants. An intrinsic paradox of the WSF is seen in the production of an aspired non-hierarchical, democratic and non-discriminatory space, which simultaneously reproduces power relations, exclusion and oppression, as we illustrated when describing the embeddedness of the "Place des Arts" in the structures surrounding it. The assemblage concept as a framework that focuses on heterogeneity and inherent tensions thereby allows 
us to underline the importance of acknowledging and thematizing structural inequalities and the reproduction of power relations, potentially encouraging activists to recognize their existence and keep fighting them.

The presentation of the space/actor debate pointed to another fundamental paradox within the WSF, highlighting seemingly opposed opinions: the coincidence of plurality and unity. We argue that assemblage thinking offers a mode of conceptualization that addresses this apparent contradiction. This important characteristic of the WSF (and other contemporary contentious phenomena) appears as the engine of a creative utopia and contributes to creating new political paradigms on a global scale, especially in the post 2010-period. It seems fundamental to us that activists and scholars recognize the existence of these paradoxes to be able to address some limitations they might pose, as well as their potentialities.

The article's reflection on the theoretical, analytical and political potential of assemblage thinking makes explicit our desire to find ways to articulate the perspectives of those striving to achieve more ecologically sustainable and socially just societies. Following the view of Conway, Thorburn and Osterweil (2016, p. 5), we maintain that "opening spaces and strengthening capacities to see the in-breaking of other possible/emergent/actual worlds is a critical epistemological and political task in the present moment." Therefore we join these scholars in the call for reflection on paradigms that acknowledge strength in plurality.

\section{References}

Auyero, J. (2005). L'espace des luttes. Topographie des mobilisations collectives. Actes de La Recherche En Sciences Sociales, 160(5), 122-132.

Butler, J. (2015). Notes toward a performative theory of assembly. Cambridge, MA: Harvard University Press.

Collier, S. J. (2006). Global assemblages. Theory, Culture \& Society, 23(2/3), 399-401.

Conway, J. (2013). Edges of global justice. The World Social Forum and its "others." New York: Routledge.

Conway, J. (2011). Cosmopolitan or colonial? The World Social Forum as "contact zone." Third World Quarterly, 32(2), 217-236.

Conway, J., Thorburn, E., \& Osterweil, M. (2016). Concept paper on assemblage thinking. Unpublished paper circulated in advance of Global Movement Assemblages Symposium, St. Catharines, ON.

De Sousa Santos, B. (2004). The World Social Forum: A User's Manual. Retrieved from $\mathrm{http}: / / \mathrm{www}$. boaventuradesousasantos.pt/documentos/fsm_eng.pdf

DeLanda, M. (2016). Assemblage theory. Edinburgh, UK: Edinburgh University Press.

DeLanda, M. (2006). A new philosophy of society: Assemblage theory and social complexity. London: Continuum.

Deleuze, G., \& Guattari, F. (1988). A thousand plateaus:Ccapitalism and schizophrenia. London: Athlone Press.

Deleuze, G., \& Parnet, C. (2007). Dialogues II. New York: Columbia University Press.

Della Porta, D., \& Mattoni, A. (2014). Spreading protest. Colchester, UK: ECPR Press.

Glasius, M. (2005). Deliberation or struggle? Civil society traditions behind the social forums. Ephemera, 5(2), 240-252. 
Gordon, U. (2018). Prefigurative politics between ethical practice and absent promise. Political Studies, 66(2), 521-537.

Hess, S., Moser, J., \& Schwertl, M. (2013). Europäisch-ethnologisches Forschen. Neue Methoden und Konzepte. Berlin, DE: Dietrich Reimer Verlag.

Kino-nda-niimi Collective. (2014). The winter we danced. Voices from the past, the future, and the Idle No More movement. Winnipeg, MB: Arbeiter Ring Publishing.

Leach, D. K. (2013). Prefigurative politics. The Wiley-Blackwell encyclopedia of social and political movements. Hoboken, NJ: Wiley-Blackwell.

Marcus, G. E., \& Saka, E. (2006). Assemblage. Theory, Culture \& Society, 23(2/3), 101-106.

Mohawk Traditional Council. (2013). Mohawk Traditional Council and Idle No More [Video file]. Retrieved from https://www.youtube.com/watch? $\mathrm{v}=\mathrm{eCBw} 4 \mathrm{x}-$ _eok

Müller, M., \& Schurr, C. (2015). Assemblage thinking and actor-network theory: Conjunctions, disjunctions, cross-fertilisations. Transactions of the Institute of British Geographers, 4l(3), 217-229.

Nail, T. (2017). What is an assemblage? SubStance, 46(1), 21-37.

O'Keefe, D. (2014). The people's social forum puts Indigenous struggles front and centre. The Source. Forum of Diversity. 15(3), 4.

Ong, A., \& Collier, S. J. (2005). Global assemblages: Technology, politics, and ethics as anthropological problems. Malden, MA: Blackwell Publishing.

Rabinow, P. (2011). The accompaniment. Assembling the contemporary. Chicago, IL: University of Chicago Press.

Schröder, C. (2015). Das Weltsozialforum eine Institution der Globalisierungskritik zwischen Organisation und Bewegung. Bielefeld, DE: Transcript Verlag.

Schwertl, M. (2013). Vom Netzwerk zum Text: die Situation als Zugang zu globalen Regimen. In S. Hess, J. Moser, \& M. Schwertl (Eds.), Europäisch-ethnologisches Forschen. Neue Methoden und Konzepte. (pp. 107-126). Berlin, DE: Dietrich Reimer Verlag.

Shore, C., Wright, S., \& Però, D. (2011). Policy worlds: Anthropology and the analysis of contemporary power. New York: Berghan Books.

Sitrin, M. (2012, March 8). Horizontalidad and territory in the occupy movements. Tikkun Magazine. Retrieved from http://www.tikkun.org/nextgen/horizontalidad-and-territory-inthe-occupy-movements

Taiaiake Alfred. (2016, October 3). Reconciliation as recolonization - Highlights. Tehaiá:iake. Retrieved from https://taiaiake.net/2016/10/03/reconciliation-as-recolonization-highlights/

Teivainen, T. (2004). The WSF: arena or actor? In J. Sen, A. Anand, A. Escobar \& P. Waterman (Eds.), World Social Forum: Challenging empires. (pp. 122-129) New Delhi, IN: The Viveka Foundation.

Whitaker, C. (2006). Changer le monde: [nouveau] mode d'emploi. Paris: Les Éditions de l'Atelier/Éditions Ouvrières.

Whitaker, C. (2004). The WSF As open space. In J. Sen, A. Anand, A. Escobar \& P. Waterman (Eds.), World Social Forum : Challenging empires. New Delhi: The Viveka Foundation.

WSF (World Social Forum). (2001). Charter of principles. Retrieved from https://fsm2016.org/en/sinformer/a-propos-du-forum-social-mondial/ 